\title{
Incidence of Bovine Enterovirus, Coronavirus, and Group A Rotavirus, and Concentration of Total Coliforms in Midwestern Pasture Streams
}

\begin{abstract}
A.S. Leaflet R2532
Douglas A. Bear, research assistant; Yong.-Il. Cho, research assistant; Jim R. Russell, professor of animal science; Steve M. Ensley, veterinarian; Kyoung-Jin Yoon, professor of veterinary diagnostic and production animal medicine
\end{abstract}

\section{Summary and Implications}

The occurrence of bovine enteric pathogens and total coliform contamination in streams of 13 Midwestern cow/calf pastures was studied during the 2007-2009 grazing seasons. Water samples $(\mathrm{n}=1274)$ were collected biweekly at up- and downstream locations on each stream. Incidence of Bovine Enterovirus (BEV), Coronavirus (BCV), and group A Rotavirus (BRV), and concentrations of total coliforms (TC) were evaluated. The mean incidences of $\mathrm{BEV}, \mathrm{BCV}$, and BRV in all samples were $3.91,1.12$, and $0.49 \%$, respectively, over the three grazing seasons. There were no differences between farms for $\mathrm{BEV}(\mathrm{P}=0.1163)$, BCV ( $\mathrm{P}=0.2977)$, and $\mathrm{BRV}(\mathrm{P}=0.5040)$ incidences, and there were no differences $(\mathrm{P}=0.3023, \mathrm{P}=0.5868, \mathrm{P}=0.1008)$ for the $\mathrm{BEV}, \mathrm{BCV}$, and $\mathrm{BRV}$ incidences between samples collected from up- or downstream locations. Incidence of BEV in up- and downstream samples were related to cattle presence in the pasture on the day, three days, and four days prior to sampling $(\mathrm{P}=0.0130, \mathrm{P}=0.0283, \mathrm{P}=0.0300$, respectively), and tended to be related to cattle presence in the pastures two days, five days, and six days prior to sampling, $(\mathrm{P}=0.0603, \mathrm{P}=0.0603, \mathrm{P}=0.0516$, respectively), but were not related to cattle presence seven days prior to sampling $(\mathrm{P}=0.2312)$. However, incidences of $\mathrm{BCV}$ or $B R V$ were not related $(\mathrm{P}>0.10)$ to cattle presence in the pastures at any time throughout the grazing seasons. In downstream samples, cattle presence in the pasture on the day of sampling only tended $(\mathrm{P}=0.0875)$ to be related to $\mathrm{BEV}$ incidence. Whereas, in upstream samples, BEV tended $(\mathrm{P}=0.0688, \mathrm{P}=0.0710, \mathrm{P}=0.0710$; respectively $)$, to be related to cattle presence in the pasture on the day, and 2 and 4 days prior to sampling. Mean TC were 1269 and 1417 colony-forming units (CFU)/100ml, respectively, for up- and downstream samples. Differences $(\mathrm{P}=0.0179)$ were observed between farms, but not between sites on farms $(P=0.3091)$, for concentrations of TC. Preliminary results indicate that the timing and management of grazing may be beneficial in decreasing the incidence of enteric viral pathogens and concentrations of TC in Midwestern pasture streams.

\begin{abstract}
Introduction
Grazing management practices that allow cattle to congregate near pasture streams may result in the loss of vegetative cover, soil compaction, and accumulation of manure near the streams. These conditions may cause sediment, phosphorus, and/or pathogen loading of streams by direct deposition of feces or in precipitation runoff.

Previous research has shown that, when compared to continuous stocking with unrestricted access to pasture streams, management practices like rotational stocking with flash-grazing of riparian paddocks or restricting stream access to stabilized crossings increased the proportion of vegetative cover and sward height of forage while reducing the proportion of ground covered with manure near streams in smooth bromegrass pastures. Therefore, nonpoint source pollution of these streams should be reduced by these practices. However, the efficacy of grazing management practices on sward height, vegetative cover, and concentration of manure are likely related to stocking rate and other factors such as the botanical composition or shade distribution in pastures that influence congregation of cattle near streams.

Grazing of cattle in streamside areas has been associated with increases in the concentrations of total coliforms (TC) in pasture streams in some studies. However, in other studies, there has been evidence of significant contributions of TC to pasture streams from other animal species, such as wildlife. Furthermore, while the presence of TC has been used as an indicator of the possible presence of pathogenic bacteria and viruses from fecal contamination, a definitive relationship has not been established. Bovine Enterovirus (BEV), Coronavirus $(\mathrm{BCV})$, and group A Rotavirus (BRV) are intestinal pathogens present in cattle feces. If these pathogens are present in water sources, they may result in scours in cattle and, possibly, bloody diarrhea in humans. Therefore, there is a need to determine whether and under what conditions these viruses are present in pasture streams to develop grazing and livestock management systems to ensure the health of both livestock and humans.

The objective of this project was to evaluate effects of stocking rate and season on the concentrations of TC and the incidence of selected enteric viral pathogens in pasture streams.
\end{abstract}

\section{Materials and Methods}

Twelve streams passing through 13 pastures on 12 cooperating farms in the Rathbun Lake watershed were identified as appropriate for the project in the fall of 2006. 
Pastures ranged in size from 7 to 265 acres and had stream reaches of 948 to 5,511 feet that drained watersheds of 624 to 13,986 acres. Grazing was controlled by the manager of each farm. Managers of these operations recorded the number of cows, heifers, and bulls stocked in these pastures as they entered and left the pasture from November, 2006 to November, 2009.

Bi-weekly from May through November, 2007, and March through November, 2008 and 2009, water samples were taken at up- and downstream locations on streams in all 13 pastures. Water samples were analyzed by the Veterinary Diagnostic Laboratory (VDL) at the Iowa State Veterinary School for incidence of BEV, BCV, and BRV by the Reverse-Transcriptase Polymerase Chain Reaction (RTPCR) and by the filter membrane method for analysis of TC concentration per $100 \mathrm{~mL}$ of sample.

The FREQ procedure of SAS was used to test the incidence of viruses found on the probability of the cattle being in the pasture on the day, 2, 3, 4, 5, 6 and 7 days prior to sampling, along with monthly and seasonal variation in $\mathrm{BEV}, \mathrm{BCV}$, and BRV incidences in up- and downstream samples. Proc REG was use to test linear, quadratic and cubic relationships of TC concentration by stocking densities of farms by period and annual stocking rate per acre and per stream foot. Proc GLM was used to test the means of the TC concentrations for up- and downstream samples and site by place interactions, taken for grazing seasons. A P-value of 0.05 was determined significant with tendency expressed by a P-value of 0.10 .

\section{Results and Discussion}

Mean incidence of samples $(n=1274$; Table 1), for BEV (49 incidences), BCV (14 incidences), and BRV (6 incidences) in water samples collected both up- and downstream were $3.91,1.12$, and $0.49 \%$, respectively. There was no difference $(\mathrm{P}>0.10)$ for incidence of $\mathrm{BEV}$, $\mathrm{BCV}$, or BRV between up and downstream samples across all farms. Incidence of BEV in upstream samples tended to be related to cattle presence on the day $(\mathrm{P}=0.0688)$, two days prior $(\mathrm{P}=0.0710)$ and four days prior $(\mathrm{P}=0.0710)$ to sampling, but downstream samples only tended to be related $(\mathrm{P}=0.0875)$ to cattle presence on the day of sampling. Incidences of BCV and BRV were not related $(\mathrm{P}>0.10)$ to the presence of cattle in the pasture at anytime during the three-year sampling period.

Incidences of BEV $(\mathrm{P}=0.0049, \mathrm{P}=0.0014)$ and $\mathrm{BCV}$ $(\mathrm{P}=0.0012, \mathrm{P}<0.0001)$ in up- and downstream samples were greater in the summer and fall, respectively, than spring, but BRV incidence did not differ $(\mathrm{P}=0.3289, \mathrm{P}=$ $0.2914)$ in up- and downstream samples between seasons. There were monthly BEV incidence differences $(\mathrm{P}=$ 0.0218; Table 3), but no differences $(\mathrm{P}>0.10)$ in $\mathrm{BCV}$ or BRV in upstream samples. Similarly, there were no differences $(\mathrm{P}>0.10)$ in BRV between months in downstream water samples. However, there were differences $(\mathrm{P}=0.0008)$ in the incidence of $\mathrm{BCV}$ and tended to be differences $(\mathrm{P}=0.0558)$ in the incidence of $\mathrm{BEV}$ between months in downstream water samples.

Concentrations of TC were regressed against cattle stocking densities for the period between samples or entire year expressed per acre or stream foot. However, no linear, quadratic, or cubic relationship existed between TC and the stocking density measures evaluated.

Means of concentrations of TC $(n=1066)$ for up- and downstream samples were 1269 and 1417 CFU/100 ml, respectively, but no differences $(\mathrm{P}<0.05)$ between up- and downstream samples $(\mathrm{P}=0.3090$; Table 4$)$. Differences $(\mathrm{P}$ $=0.0179$ ) were observed between farms, but large variations in concentrations occurred between up- and downstream samples.

Results imply that while grazing cattle may contribute to loading of pasture streams with fecal coliforms and enteric viruses, substantial numbers of the bacteria and viruses may be present in stream water entering pastures. The relationships between the incidences of enteric viruses and cattle presence imply that the incidences of the enteric viruses may be short-lived. Therefore, both infection of cows and calves and loading of streams with enteric viruses may be controlled by grazing management practices that alter the temporal/spatial distribution of grazing cattle.

\section{Acknowledgements}

The authors would like to thank the cooperating producers, USDA-NRCS personnel, and technical staff of the VDL at Iowa State University for their assistance with this project, and Garritt Page for assistance with statistical analysis. The material in this report is based on the work supported by the Cooperative State Research, Education, and Extension Service, U.S. Department of Agriculture, under Award No. 2007-35102-18115. Any opinions, findings, conclusions, or recommendations expressed in this publication are those of the authors and do not necessarily reflect the views of the U. S. Department of Agriculture. 
Table 1. Incidences of BEV, BCV, and BRV in water samples collected at upstream and downstream locations from 13 pastures on 12 farms during the 2007, 2008, and 2009 grazing seasons.

\begin{tabular}{|c|c|c|c|c|c|c|}
\hline \multirow{3}{*}{ Pasture } & \multicolumn{6}{|c|}{ Incidence } \\
\hline & \multicolumn{2}{|c|}{ BEV } & \multicolumn{2}{|c|}{ BCV } & \multicolumn{2}{|c|}{ BRV } \\
\hline & Upstream & Downstream & Upstream & Downstream & Upstream & Downstream \\
\hline 1 & 1 & 1 & 0 & 2 & 0 & 2 \\
\hline 2 & 4 & 3 & 0 & 0 & 0 & 1 \\
\hline 3 & 0 & 1 & 0 & 0 & 0 & 0 \\
\hline 4 & 0 & 1 & 0 & 2 & 0 & 1 \\
\hline 5 & 2 & 3 & 1 & 0 & 1 & 0 \\
\hline 6 & 0 & 1 & 0 & 2 & 0 & 1 \\
\hline 7 & 1 & 5 & 2 & 1 & 0 & 0 \\
\hline 8 & 2 & 3 & 1 & 1 & 0 & 0 \\
\hline 9 & 1 & 2 & 0 & 0 & 0 & 0 \\
\hline 10 & 4 & 4 & 1 & 1 & 0 & 0 \\
\hline 11 & 1 & 0 & 0 & 0 & 0 & 1 \\
\hline 12 & 3 & 1 & 1 & 1 & 0 & 0 \\
\hline 13 & 1 & 1 & 0 & 0 & 0 & 0 \\
\hline Incidence & 21 & 28 & 6 & 8 & 1 & 5 \\
\hline $\begin{array}{c}\text { Percent } \\
\text { Incidence }\end{array}$ & 3.34 & 4.47 & 0.96 & 1.28 & 0.16 & 0.80 \\
\hline
\end{tabular}

Table 2. Monthly incidences of BEV, BCV, and BRV in water samples collected at upstream and downstream locations from 13 pastures on 12 farms during the 2007, 2008, and 2009 grazing seasons.

\begin{tabular}{|c|c|c|c|c|c|c|}
\hline & \multicolumn{9}{|c|}{ BEV } & \multicolumn{2}{c|}{ BCV } & \multicolumn{2}{c|}{ BRV } \\
\hline Month & \multicolumn{2}{|c|}{ BEV } & Upstream & Downstream & Upstream & Downstream \\
\hline & Upstream & Downstream & 0 & 0 & 0 & 0 \\
\hline March & 1 & 1 & 0 & 0 & 0 & 1 \\
\hline April & 0 & 1 & 0 & 0 & 0 & 2 \\
\hline May & 0 & 0 & 0 & 0 & 0 & 0 \\
\hline June & 0 & 1 & 0 & 0 & 0 & 0 \\
\hline July & 6 & 9 & 0 & 0 & 0 & 0 \\
\hline August & 2 & 5 & 2 & 2 & 0 & 0 \\
\hline September & 6 & 6 & 2 & 6 & 1 & 2 \\
\hline October & 6 & 3 & 2 & 0 & 0 & 0 \\
\hline November & 0 & 2 & $\mathbf{6}$ & $\mathbf{8}$ & $\mathbf{1}$ & $\mathbf{5}$ \\
\hline Incidence & $\mathbf{2 1}$ & $\mathbf{2 8}$ & & & & 0 \\
\hline
\end{tabular}


Table 3. Mean concentration of fecal coliforms in water samples collected at upand downstream locations from 13 pastures on 12 farms during the 2007, 2008, and 2009 grazing seasons.

\begin{tabular}{|c|c|c|}
\hline & \multicolumn{2}{|c|}{ Sampling location } \\
\hline Pasture & Upstream & Downstream \\
\hline & \multicolumn{2}{|c|}{ CFU/100 ml } \\
\hline 1 & $1086^{\mathrm{xy}}$ & $1552^{\mathrm{y}}$ \\
\hline 2 & $1822^{\mathrm{b}, \mathrm{x}}$ & $2686^{\mathrm{a}, \mathrm{x}}$ \\
\hline 3 & $1432^{\mathrm{xy}}$ & $868^{\mathrm{y}}$ \\
\hline 4 & $863^{\mathrm{xy}}$ & $957^{\mathrm{y}}$ \\
\hline 5 & $863^{\mathrm{xy}}$ & $1252^{\mathrm{y}}$ \\
\hline 6 & $1118^{\mathrm{xy}}$ & $1312^{\mathrm{y}}$ \\
\hline 7 & $1802^{\mathrm{x}}$ & $1621^{\mathrm{y}}$ \\
\hline 8 & $1152^{\mathrm{xy}}$ & $1446^{\mathrm{y}}$ \\
\hline 9 & $1137^{\mathrm{xy}}$ & $1228^{\mathrm{y}}$ \\
\hline 10 & $1781^{\mathrm{x}}$ & $1692^{\mathrm{xy}}$ \\
\hline 11 & $838^{\mathrm{xy}}$ & $1189^{\mathrm{y}}$ \\
\hline 12 & $1575^{\mathrm{xy}}$ & $1445^{\mathrm{y}}$ \\
\hline 13 & $1033^{\mathrm{xy}}$ & $1173^{\mathrm{y}}$ \\
\hline
\end{tabular}

${ }^{\mathrm{a}, \mathrm{b}}$ Within a row, least squares means without a common subscript differ $(\mathrm{P}<0.10)$.

${ }^{\mathrm{x}, \mathrm{y}}$ Within a column, least squares means without a common subscript $\operatorname{differ}(\mathrm{P}<0.10)$. 